\title{
Palaeoecology of the Holsteinian lake in vicinity of Wilczyn (eastern Poland) based on molluscan studies
}

\author{
Marcin SZYMANEK ${ }^{1, *}$ \\ 1 Faculty of Geology, University of Warsaw, Żwirki i Wigury 93, 02-089 Warszawa, Poland
}

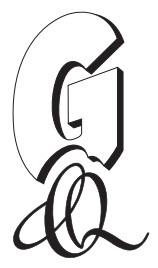

\begin{abstract}
Szymanek M. (2013) Palaeoecology of the Holsteinian lake in vicinity of Wilczyn (eastern Poland) based on molluscan studies. Geological Quarterly, 57 (4): 637-648, doi 10.7306/gq.1120

Malacological studies of two profiles of the Holsteinian (Mazovian) Interglacial from eastern Poland - Roskosz and Wilczyn $1 / 12$ - are presented. They are connected with the northern part of the Wilczyn palaeolake and seems to document palaeoecological changes in the part of the climatic optimum and the post-optimal period. Mollusc communities are typical of lake environs. The latter is supported by biometry of Pisidium moitessierianum. Higher energy conditions are evidenced by rheophile species $P$. henslowanum and $P$. nitidum in the lowermost part of the Roskosz section. Mollusc assemblages with Lithoglyphus jahni, with Valvata piscinalis and Bithynia tentaculata as well as with Valvata piscinalis are distinguished at Roskosz. They record changes in aquatic vegetation and depth conditions. Malacofauna from Wilczyn $1 / 12$ is dominated by $V$. piscinalis, V. piscinalis f. antiqua and B. tentaculata. Limited contribution of temperate gastropods Viviparus diluvianus and $L$. jahni as well as the occurrence of some cold-loving forms indicate a deterioration of thermal conditions. Shallow-water habitats and expansion of reed zones are inferred from proportions of Bithynia shells and opercula.
\end{abstract}

Key words: palaeoecology, molluscs, Holsteinian, lacustrine sediments.

\section{INTRODUCTION}

The study area is located in eastern Poland in the South Podlasie region, ca. $6 \mathrm{~km} \mathrm{NE}$ of Biała Podlaska (Fig. 1). It is a part of a vast palaeolake district of the Holsteinian (Mazovian) Interglacial (MIS 11) described among others by Nitychoruk (1994, 2000), Albrycht et al. (1997) as well as Lindner and Marciniak (1997, 1998). Lake deposits of the Holsteinian age are known from over thirty locations in the region. In some of them, for example Ossówka (Nitychoruk, 1994, 2000; Szymanek, 2007, 2008, 2011), Hrud (Lindner et al., 1991; Nitychoruk, 1994; Szymanek, 2007, 2011, 2012), Ortel Królewski, Szymanowo (Albrycht et al., 1995; Szymanek, 2007, 2008, 2011) and Roskosz (Albrycht et al., 1995), an abundant mollusc fauna is present.

Two new profiles under investigation are connected with the northern part of a vast trough palaeolake stretched from Wilczyn to Woskrzenice or even to Lachówka Mała (Nitychoruk and Gałazka, 2006; Fig. 1). It existed since the end of the Elsterian Glaciation (MIS 12) and its origin is connected with the tectonic predisposition to subsidence due to ice-sheet loading, favouring the survival of dead-ice blocks of the Elsterian age (Nitychoruk, 1994, 2000; Bińka et al., 1997). The accumulation of lake deposits took place in the end of the Elsterian, through

\section{*E-mail: m.szymanek@uw.edu.pl}

Received: March 18, 2013; accepted: July 8, 2013; first published online: September 24, 2013 the whole Holsteinian, to the early stage of the Saalian Glaciation (MIS 10) (Bińka et al., 1997; Krupiński, 2000; Nitychoruk, 2000). The lake history is recorded in thick lacustrine chalk and calcareous gyttja, multidisciplinary investigated at many profiles (e.g., Bińka and Nitychoruk, 1995, 1996; Bińka et al., 1997; Nitychoruk, 2000; Nitychoruk et al., 2005). The late glacial of the Elsterian and the initial part of the Holsteinian Interglacial were documented at Woskrzenice (Bińka and Nitychoruk, 1995). Pollen spectra from Wilczyn - WL-1 (Bińka, 1994; Bińka et al., 1997) covers the climatic optimum and post-interglacial period, whereas the most complete pollen diagram from Kaliłów presents pre-interglacial tundra and the entire interglacial succession (Bińka and Nitychoruk, 1996). A similar interval was also yielded by a few boreholes from the vicinity of Grabanów in the southern part of the basin (Krupiński, 1995, 2000). In all of the mentioned profiles, lake deposits of the Holsteinian age lie on till and glaciofluvial sands of the Elsterian Glaciation. Beneath, glaciogenic series of the Cromerian Complex and Menapian Glaciation were documented (Nitychoruk, 1994; Bińka et al., 1997; Nitychoruk and Gałazka, 2006).

The accumulation of mollusc-bearing deposits was connected with the near shore zone of the lake. Notes on sediments with malacofauna were firstly made in the southern part of the Grabanów village (GR st. 1), where they occur "in situ" (Krupiński and Skompski, 1995) and in the western part of the village, in the gravel pit, where they are glaciotectonically disturbed (Fig. 1). They represent fragments of the coastal berm pushed out in the Saalian Glaciation (Lindner and Wyrwicki, 1996; Bińka et al., 1997). In the northern part of the lake they were found in the 1960s and were documented on the Detailed Geological Map of Poland 1:50,000, the sheet Biała Podlaska 


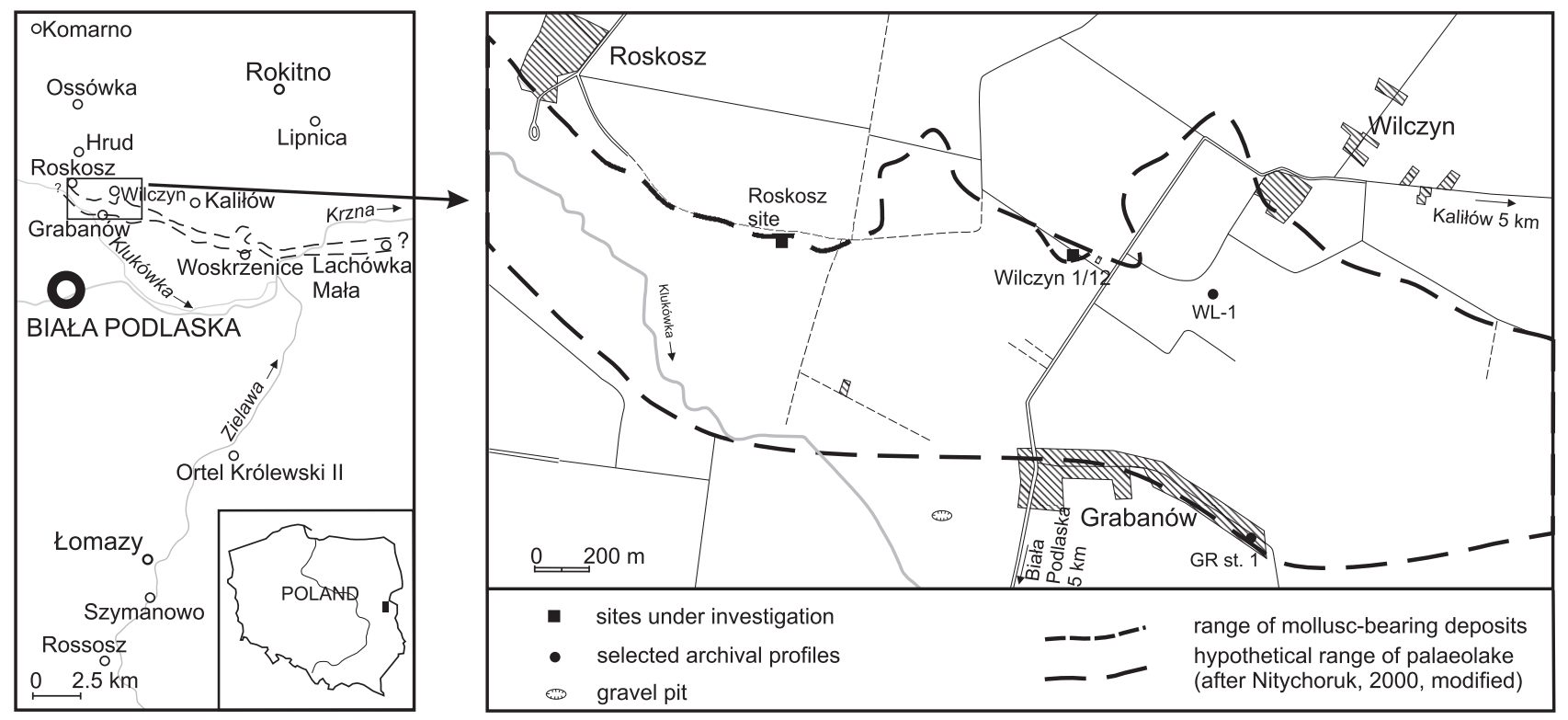

Fig. 1. Location sketch of study area

(Nitychoruk and Gałązka, 2006). No signs of disturbance were noted; however, they were not subjected to a detailed malacological analysis. Only biometric studies on Viviparus diluvianus shells were conducted at the Roskosz site, with a brief description of the accompanying snails (Szymanek, 2007, 2011). The present paper provides a detailed description and analysis of the structure of the mollusc assemblage from Roskosz. The new profile, bored in spring 2012 and described as Wilczyn $1 / 12$, is also investigated (Fig. 1). The principal aim of the study was to reconstruct environmental conditions in the Wilczyn palaeolake on the basis of malacological data of both sites. Studies on changes in aquatic vegetation and water depth were also conducted.

\section{GEOLOGICAL SETTING}

Both profiles under investigation are located between the small villages of Roskosz and Wilczyn (Fig. 1), in the northern part of the vast depression documented as a palaeolake basin of the Holsteinian age (Bińka and Nitychoruk, 1996; Bińka et al., 1997; Nitychoruk, 2000). The Roskosz site (GPS: 524'25” N; $23^{\circ} 8^{\prime} 24^{\prime \prime} \mathrm{E}$ ) is situated ca. $1 \mathrm{~km}$, whereas the Wilczyn profile (GPS: $52^{\circ} 4^{\prime} 23^{\prime \prime} \mathrm{N}$; 239'20" E) is located ca. $155 \mathrm{~m} \mathrm{NW}$ of route Biała Podlaska-Wilczyn (Fig. 1). Mollusc shells are concentrated along the shores of the palaeolake in belts up to $500 \mathrm{~m}$ long and $100 \mathrm{~m}$ wide. They appear on the surface or under a thin cover of slope deposits. The central part of the basin is filled with calcareous gyttja and lacustrine chalk with a total thickness of over $35 \mathrm{~m}$, which are covered by silts and clays accumulated in the initial part of the Saalian Glaciation (Bińka and Nitychoruk, 1996; Bińka et al., 1997; Nitychoruk, 2000).

The geological profile at Roskosz begins at the depth of ca. $2.4 \mathrm{~m}$ with a horizon of clayey silt, which is greenish-gray in colour. At $1.6 \mathrm{~m}$ a $10 \mathrm{~cm}$ layer of a blue sandy silt occurs, which is covered by deposits with abundant mollusc shells - a sand of mixed grain size, greenish-gray in colour (depth of 1.35-1.5 m); a medium-grained sand, brownish in colour (1.2-1.35 m); a grey sandy silt $(0.8-1.2 \mathrm{~m})$ and a yellow clayey sand $(0.6-0.8 \mathrm{~m})$. Above a $30 \mathrm{~cm}$ thick layers of colluvial sand and soil are distinguished. Malacofauna make up ca. $60 \%$ of the deposit volume and are very well preserved. Both the occurrence of extinct gastropods Viviparus diluvianus and Lithoglyphus jahni shells and the pollen spectra points to the Holsteinian age of the sediments (Szymanek, 2011). Both species are unknown after the Holsteinian Interglacial and in Poland $V$. diluvianus was found only in deposits of that age. Higher frequency of Quercus and Carpinus pollen at interval of 0.8-1.05 m may suggest the optimal, Carpinus-Abies zone of the Holsteinian Interglacial (K. Bińka, pers. comm., 2011); however, the low content and poor preservation of sporomorphs hinder the interpretation (Szymanek, 2011).

The mollusc-bearing deposits at Wilczyn are $0.9 \mathrm{~m}$ thick. The geological profile starts at the depth of $2.1 \mathrm{~m}$. A total of nine layers can be distinguished from the bottom: gyttja with organic remains, greenish-gray in colour (up to depth of $1.8 \mathrm{~m}$ ); sandy silt with malacofauna and organic remains, grey in colour (1.7-1.8 m); greyish-yellow clay with malacofauna and organic remains $(1.6-1.7 \mathrm{~m})$; clayey silt, sandy in its upper part, with abundant mollusc shells and single organic remains, grey (1.2-1.6 m); sandy silt with single molluscs, greyish-yellow in colour (0.9-1.2 m); clayey silt, greyish-yellow in colour $(0.7-0.9 \mathrm{~m})$ and dark grey mud $(0.5-0.7 \mathrm{~m})$. The latter is covered by the organic soil, dark brown in colour. Similarly as in the Roskosz profile, $V$. diluvianus and $L$. jahni shells are present in deposits, which may support their Holsteinian age. A description of the pollen spectra is given below.

\section{MATERIAL AND METHODS}

At Roskosz a total of 6 samples at $10 \mathrm{~cm}$ intervals were collected from a small excavation ca. $0.8 \mathrm{~m}$ wide, $2 \mathrm{~m}$ long and $1.6 \mathrm{~m}$ deep. They were taken from the top of the profile downwards from every distinguished layer of deposits with molluscs, i.e. in the depth interval of $0.6-1.5 \mathrm{~m}$. Each of the sand layers was represented by one sample, whereas from silty deposits (0.8-1.2 $\mathrm{m})$ three samples were collected. At Wilczyn 1/12 the material originates from a borehole with diameter of $10 \mathrm{~cm}$. Seven malacological samples were taken at the depth of 
1.1-1.8 $\mathrm{m}$ from $10 \mathrm{~cm}$ intervals. Eight samples (depth of 1.1-1.9 m) were palynologically investigated by K. Bińka, Faculty of Geology, University of Warsaw.

The mollusc analysis was carried out in accordance with methodology established by Ložek (1964), Alexandrowicz (1987) and Alexandrowicz and Alexandrowicz (2011). Samples of volume of ca. 3 litres (Roskosz) and of 0.5-1.1 litres (Wilczyn) were macerated and washed on a $0.5 \mathrm{~mm}$ mesh. All mollusc shells and their fragments were picked from dried residuum, identified and counted under low power binocular microscope. Some damaged specimens were determined only to the genus level. According to ecological preferences of identified molluscs, they were grouped into open country snails (5), species of very damp, swampy, periodically flooded sites (9), species of temporary water bodies (10), species of permanent water bodies of stagnant waters (11) and species of flowing waters (12). In addition eight supplementary classes were distinguished after Ložek (1964, 1976, 1982), Körnig, (1966), Piechocki (1979), Skompski and Makowska (1989) (see Tables 1 and 3 ). The mollusc composition and its changes in the profiles were illustrated by malacological spectra of species (MSS) and specimens (MSI) (see Figs. 2 and 5) as well as by malacological diagrams (see Figs. 3 and 6). The Bithynia-index (BIN) (Steenberg, 1917; Alexandrowicz W.P., 1987, 1999, 2004, 2007; Alexandrowicz S.W., 1987, 1999) was counted to characterize evolution of vegetation and depositional environments. This shows relations between shells and opercula of Bithynia tentaculata, which are sorted in the littoral of water bodies and accumulate in well-vegetated zones with reeds and bullrushes (opercula; BIN close to +1) or along the shores (shells; BIN close to -1) (Steenberg, 1917; Alexandrowicz S.W., 1999).

Basic biometric studies were conducted on the bivalve Pisidium moitessierianum. Due to the low frequency of this species in the Wilczyn profile, biometric methods were applied only at Roskosz. Bivalves were measured under the binocular with a use of micrometer eyepiece. Length $(L)$ and height $(H)$ of the shell, as well as the ratio of these parameters $(\mathrm{L} / \mathrm{H})$ were measured for each specimen. The latter was used to determine the lacustrine or fluvial ecotype of $P$. moitessierianum (Brodniewicz, 1960).

\section{RESULTS}

\section{ROSKOSZ SITE}

\section{MOLLUSC COMPOSITION}

The mollusc assemblage at Roskosz is composed of 36 taxa (19 of snails and 17 of bivalves) represented by 32,218 specimens. The number of taxa varies from 22 to 30 , whereas number of specimens fluctuates between 2,686 and 7,274 with the greatest abundance in the middle part of the section (sample 3; depth of 0.95-1.05 m; Fig. 2). Species of 4 ecological groups and 7 supplementary classes were distinguished in the community (Table 1).

Species of damp and swampy habitat (9). Group represented by one species - Succinea putris. Habitats of this land snail are usually connected with wet environs and shores of water bodies (Kerney et al., 1983; Wiktor, 2004). Only single individuals are noted in samples 2 and 3 (Table 1).

Species of temporary water bodies (10). Three snail species - Valvata cristata, Galba truncatula, Segmentina nitida and one bivalve - Pisidium milium, represented by single speci- mens, are present in this group. Only V. cristata typical of shallow, intensively overgrown water bodies has slightly higher frequency (Table 1).

Species of permanent water bodies of stagnant waters (11). The most abundant group in the mollusc community, composed of 11 species of snails and 8 species of bivalves. The most numerous are snails noted both in stagnant and flowing waters - Lithoglyphus jahni, Valvata piscinalis, Viviparus diluvianus and Bithynia tentaculata as well as $V$. piscinalis $\mathrm{f}$. antiqua, which is a typical lake specimen (Piechocki, 1979). V. diluvianus and $L$. jahni have stratigraphical significance. The ecological tolerance of $L$. jahni can be disputable. It may be treated as a river species (Gittenberger et al., 2004; Kondrashov, 2007), however, Urbański (1975) as well as Skompski and Makowska (1989) join it with both lake and fluvial sediments. Noteworthy is also a presence of Acroloxus lacustris, Gyraulus albus and Lymnaea stagnalis, which inhabit zones with rich aquatic vegetation (Piechocki, 1979; Glöer, 2002).

Among bivalves the most frequent is Pisidium henslowanum. This eurytopic species often inhabits water bodies with overflow (Piechocki and Dyduch-Falniowska, 1993). P. lilljeborgi and $P$. hibernicum are lake specimens (Piechocki and Dyduch-Falniowska, 1993), whereas P. moitessierianum inhabits both rivers and lakes creating different conchological forms (Brodniewicz, 1960).

Species of flowing waters (12). All representatives of the group are bivalves. Flowing waters are preferred by Unio pictorum, Pisidium supinum and $P$. amnicum. The latter is often present in the shore zone of lakes with strong wave action (Piechocki and Dyduch-Falniowska, 1993). The most abundant are eurytopic $P$. nitidum and $P$. subtruncatum usually connected with fluvial habitats (Table 1; Piechocki and DyduchFalniowska, 1993; Alexandrowicz and Alexandrowicz, 2011).

\section{MOLLUSC ASSEMBLAGE AND THE ENVIRONMENT}

Mollusc community from Roskosz is connected with the lacustrine environment, which is supported by Valvata piscinalis $\mathrm{f}$. antiqua, Acroloxus lacustris and Pisidium lilljeborgii. The Holsteinian age of the malacocenoses is confirmed by the presence of Viviparus diluvianus, Lithoglyphus jahni as well as by the pollen spectra enriched in Quercus and Carpinus (Szymanek, 2011). Due to the bad state of preservation of pollen grains it is hard to estimate the exact time of accumulation of mollusc-bearing deposits. However, higher frequencies of oak and hornbeam may point to the optimal part of the interglacial (the Carpinus-Abies zone) (Szymanek, 2011).

Environmental conditions were favourable for molluscs and rather stable as is shown by the quantity of molluscs and small fluctuations in the number of species and specimens (Fig. 2). Ecological changes in the water body may be drawn on the basis of the relation between different groups of molluscs. Land species of damp and swampy habitat (ecological group 9) and species of temporary water bodies (group 10) has secondary significance at Roskosz, being an accessory element of the fauna. The mollusc community is characterized by the predomination of snails and bivalves of stagnant waters (group 11) over rheophile species (group 12). They reach up to $85 \%$ of all species and $99 \%$ of specimens present in the sediments. Species of fluvial environs makes between 9 and $25 \%$ of malacocenoses. The number of the specimens is low $(1-5 \%$ of the assemblage), which suggests rather restricted water movements (Fig. 2). An occasional overflow in the lowermost part of the section can be inferred from higher frequencies of Pisidium henslowanum and P. nitidum (Piechocki, 1979; Skompski, 1983, 1989). 
Malacofauna of the Roskosz profile

\begin{tabular}{|c|c|c|c|c|c|c|c|c|}
\hline \multirow{2}{*}{ I } & \multirow{2}{*}{ II } & \multirow{2}{*}{ Taxon } & \multicolumn{6}{|c|}{ Samples } \\
\hline & & & 1 & 2 & 3 & 4 & 5 & 6 \\
\hline 9 & WD & Succinea putris (Linnaeus) & & 7 & 4 & & & \\
\hline 10 & Wp & Valvata cristata Müller & 5 & 14 & & 4 & & \\
\hline 10 & Wd & Galba truncatula (Müller) & 3 & 2 & 2 & & & \\
\hline 10 & WP & Segmentina nitida (Müller) & & & & & 1 & \\
\hline 10 & We & Pisidium milium Held & & & 1 & & & \\
\hline 11 & We & Viviparus diluvianus (Kunth) & 422 & 521 & 498 & 474 & 249 & 161 \\
\hline 11 & We & $\begin{array}{l}\text { Bithynia tentaculata (Linnaeus) } \\
(+ \text { operculum) }\end{array}$ & $\begin{array}{r}84 \\
286\end{array}$ & $\begin{array}{l}207 \\
595\end{array}$ & $\begin{array}{l}183 \\
589\end{array}$ & $\begin{array}{l}205 \\
846\end{array}$ & $\begin{array}{r}26 \\
134\end{array}$ & $\begin{array}{l}18 \\
18\end{array}$ \\
\hline 11 & We & Lithoglyphus jahni Urbański & 1197 & 1275 & 1687 & 1911 & 1960 & 1099 \\
\hline 11 & We & Valvata piscinalis Müller & 2832 & 1828 & 3582 & 2917 & 1586 & 746 \\
\hline 11 & WL & $\begin{array}{l}\text { Valvata piscinalis f. antiqua } \\
\text { Sowerby }\end{array}$ & 276 & 265 & 364 & 390 & 308 & 288 \\
\hline 11 & WL & Acroloxus lacustris (Linnaeus) & & 15 & 9 & 9 & & 1 \\
\hline & & Radix sp. & 3 & 2 & 2 & 2 & & \\
\hline 11 & WL & Lymnaea stagnalis (Linnaeus) & 30 & 34 & 35 & 30 & 2 & 3 \\
\hline 11 & WL & Planorbarius corneus (Linnaeus) & 1 & 1 & 1 & 1 & & \\
\hline 11 & WL & Planorbis carinatus Müller & & 3 & 5 & & & \\
\hline & & Anisus sp. & 1 & & 1 & 1 & & \\
\hline 11 & We & Gyraulus albus (Müller) & 48 & 145 & 155 & 140 & 14 & 3 \\
\hline 11 & WL & Gyraulus crista (Linnaeus) & & 2 & & & & \\
\hline & & Gyraulus sp. & 67 & 111 & 65 & 49 & 6 & 6 \\
\hline 11 & We & Sphaerium corneum (Linnaeus) & 4 & 5 & 5 & 5 & 10 & 8 \\
\hline & & Sphaerium sp. & 3 & 4 & 2 & 2 & 4 & 2 \\
\hline 11 & We & Pisidium casertanum (Poli) & 3 & 6 & 2 & 2 & 35 & 29 \\
\hline 11 & We & $\begin{array}{l}\text { Pisidium casertanum f. ponderosa } \\
\text { Stelfox }\end{array}$ & 4 & 2 & 1 & 1 & 12 & 9 \\
\hline 11 & We & Pisidium henslowanum (Sheppard) & 5 & 15 & 15 & 27 & 81 & 50 \\
\hline 11 & WL & Pisidium lilljeborgii Clessin & & 3 & 2 & 4 & 7 & 4 \\
\hline 11 & WL & Pisidium hibernicum Westerlund & & 1 & & 1 & & \\
\hline 11 & We & Pisidium moitessierianum Paladilhe & 5 & & 1 & 2 & 52 & 11 \\
\hline 11 & We & Pisidium crassum Stelfox & & & 6 & 8 & 33 & 36 \\
\hline 12 & Wc & Unio pictorum (Linnaeus) & & & & & 6 & 2 \\
\hline 12 & We & Unio tumidus Philipsson & 1 & & 1 & & 10 & 1 \\
\hline 12 & & Unio sp. & 3 & 1 & 1 & 2 & & \\
\hline 12 & Wc & Pisidium amnicum (Müller) & 2 & & & & & 1 \\
\hline 12 & Wc & Pisidium supinum A. Schmidt & 1 & & 1 & & & \\
\hline 12 & We & Pisidium nitidum Jenyns & 16 & 24 & 27 & 32 & 106 & 104 \\
\hline 12 & We & Pisidium subtruncatum Malm & 5 & 4 & 7 & 12 & 20 & 20 \\
\hline & & Pisidium sp. & 15 & 23 & 20 & 21 & 61 & 66 \\
\hline
\end{tabular}

I - ecological groups (after Ložek, 1964; Alexandrowicz S.W., 1987): 9 - species of damp and swampy habitat, 10 - species of temporary water bodies, 11 - species of permanent water bodies of stagnant waters, 12 species of flowing waters; II - supplementary ecological symbols (after Ložek, 1964, 1976, 1982; Körnig, 1966; Piechocki, 1979; Skompski and Makowska, 1989): WD - snails of swamps, flooded meadows and shores of water bodies, Wd - amphibiotic species of marshy and water environs, WP - molluscs of episodic, periodically drying out water bodies, $\mathrm{Wp}$ - molluscs of shallow, intensively overgrown water bodies, $\mathrm{WL}-\mathrm{spe}-$ cies of permanent water bodies of various size, We - species present both in rivers and lakes, in stagnant and flowing waters, Wc - species preferring flowing waters with weak current; 14 - number of specimens

Three mollusc assemblages corresponding with the succeeding phases of lake development can be distinguished at Roskosz. The first one (samples 5 and 6; the depth of $1.25-1.50 \mathrm{~m}$ ) is dominated by Lithoglyphus jahni. It makes up over $40 \%$ of the assemblage. Among the accompanying species Valvata piscinalis, V. piscinalis f. antiqua and Viviparus diluvianus should be mentioned. Quite abundant shells of Pisidium henslowanum, $P$. moitessierianum and $P$. nitidum are also noted (Fig. 3). The river flowing through the lake is possible at that time.

The second assemblage (samples 2-4, the depth of $0.8-1.2 \mathrm{~m}$ ) is dominated by Valvata piscinalis and Bithynia 
Table 2

Biometry of Pisidium moitessierianum from selected samples of the Roskosz site

\begin{tabular}{|c|c|c|c|c|c|c|}
\hline Sample 1 & \multicolumn{5}{|c|}{ Height $(\mathrm{H})$} & \multirow[t]{2}{*}{ Total } \\
\hline Length (L) & $0.8-1.0$ & $1.0-1.2$ & $1.2-1.4$ & $1.4-1.6$ & $1.6-1.8$ & \\
\hline $1.4-1.6$ & & 1 & 5 & 1 & & 7 \\
\hline $1.6-1.8$ & & & & 2 & & 2 \\
\hline Total & & 1 & 5 & 3 & & 9 \\
\hline \multicolumn{7}{|c|}{$L_{\min }=1.4 ; L_{\max }=1.67 ; \mathrm{H}_{\min }=1.3 ; \mathrm{H}_{\max }=1.52$} \\
\hline & \multicolumn{5}{|c|}{ Length (L) } & Total \\
\hline L/H & $1.0-1.2$ & $1.2-1.4$ & $1.4-1.6$ & $1.6-1.8$ & $1.8-2.0$ & \\
\hline $1.0-1.05$ & & 1 & 1 & & & 2 \\
\hline $1.05-1.10$ & & 1 & 1 & 1 & & 3 \\
\hline $1.10-1.15$ & & & 3 & & & 3 \\
\hline $1.15-1.20$ & & & & 1 & & 1 \\
\hline Total & & 2 & 5 & 2 & & 9 \\
\hline Mean L/H & & 1.06 & 1.1 & 1.13 & & 1.1 \\
\hline Sample 5 & \multicolumn{5}{|c|}{ Height $(\mathrm{H})$} & Total \\
\hline Length (L) & $0.8-1.0$ & $1.0-1.2$ & $1.2-1.4$ & $1.4-1.6$ & $1.6-1.8$ & \\
\hline $1.0-1.2$ & 1 & & & & & 1 \\
\hline $1.2-1.4$ & & 6 & 4 & & & 10 \\
\hline $1.4-1.6$ & & 1 & 54 & 15 & & 70 \\
\hline $1.6-1.8$ & & & 2 & 10 & 1 & 13 \\
\hline Total & 1 & 7 & 60 & 25 & 1 & 94 \\
\hline \multicolumn{7}{|c|}{$L_{\min }=1.1 ; L_{\max }=1.8 ; H_{\min }=1.0 ; H_{\max }=1.72$} \\
\hline & \multicolumn{5}{|c|}{ Length $(\mathrm{L})$} & Total \\
\hline $\mathrm{L} / \mathrm{H}$ & $1.0-1.2$ & $1.2-1.4$ & $1.4-1.6$ & $1.6-1.8$ & $1.8-2.0$ & \\
\hline $1.0-1.05$ & & & 2 & 1 & & 3 \\
\hline $1.05-1.10$ & 1 & 2 & 32 & 8 & & 43 \\
\hline $1.10-1.15$ & & 8 & 30 & 2 & & 40 \\
\hline $1.15-1.20$ & & 4 & 2 & 1 & & 7 \\
\hline $1.20-1.25$ & & & & 1 & & 1 \\
\hline Total & 1 & 14 & 66 & 13 & & 94 \\
\hline Mean L/H & 1.1 & 1.14 & 1.1 & 1.1 & & 1.11 \\
\hline Sample 6 & \multicolumn{5}{|c|}{ Height $(\mathrm{H})$} & Total \\
\hline Length (L) & $0.8-1.0$ & $1.0-1.2$ & $1.2-1.4$ & $1.4-1.6$ & $1.6-1.8$ & \\
\hline $1.2-1.4$ & & 2 & 1 & & & 3 \\
\hline $1.4-1.6$ & & & 15 & 2 & & 17 \\
\hline $1.6-1.8$ & & & & & 1 & 1 \\
\hline Total & & 2 & 16 & 2 & & 21 \\
\hline \multicolumn{7}{|c|}{$L_{\min }=1.35 ; L_{\max }=1.69 ; H_{\min }=1.15 ; H_{\max }=1.62$} \\
\hline & \multicolumn{5}{|c|}{ Length (L) } & Total \\
\hline $\mathrm{L} / \mathrm{H}$ & $1.0-1.2$ & $1.2-1.4$ & $1.4-1.6$ & $1.6-1.8$ & $1.8-2.0$ & \\
\hline $1.0-1.05$ & & & 1 & 1 & & 2 \\
\hline $1.05-1.10$ & & 1 & 9 & & & 10 \\
\hline $1.10-1.15$ & & 1 & 6 & & & 7 \\
\hline $1.15-1.20$ & & 1 & 1 & & & 2 \\
\hline Total & & 3 & 17 & 1 & & 21 \\
\hline Mean L/H & & 1.13 & 1.1 & 1.04 & & 1.09 \\
\hline
\end{tabular}

tentaculata (Fig. 3). Fluctuations in the abundance of these species may suggest some changes of the water level. $B$. tentaculata occupies more shallow zones of water bodies $(0.7-1.8 \mathrm{~m})$, while $V$. piscinalis is usually connected with depths of 8-10 m (Piechocki, 1979; Alexandrowicz, 1987; Alexandrowicz, 2007, 2008). Dominance of Bithynia opercula (BIN 0.48-0.68) points to the growth of bullrushes and reeds (Alexandrowicz and Sanko, 1997; Alexandrowicz W.P., 1999, 2004, 2008). The overgrowing of the near shore zone favoured an expansion of pulmonates. The frequency of plant associated species - Lymnaea stagnalis, Gyraulus albus, Acroloxus lacustris, Planorbis carinatus increases distinctly in the upper part of the succession. V. diluvianus and $V$. piscinalis $f$. antiqua are constant element of the fauna, the number of $L$. jahni is reduced to ca. $25 \%$ (Fig. 3 ).

The third assemblage (sample 1, the depth of $0.65-0.75 \mathrm{~m}$ ) is characterized by the dominance of Valvata piscinalis (Fig. 3). According to Alexandrowicz (2009) this association is typical of littoral zone, usually free of plants. At Roskosz drop in the number of $B$. tentaculata is noted. Its opercula are still more numerous than shells, but contribution of forms of rich vegetation (e.g., Gyraulus albus, Acroloxus lacustris, V. cristata) diminishes distinctly. Probably the plant cover was limited due to deepening of the lake. $V$. diluvianus, $V$. piscinalis $\mathrm{f}$. antiqua and $L$. jahni occur in abundance similar to the lower parts of the profile (Fig. 3).

\section{CLUSTER ANALYSIS}

A dendrogram produced by cluster analysis reflects the mollusc assemblages described at Roskosz (Fig. 4). Horn's overlap index for abundance data was used in clustering routine in the PAST programme (Horn, 1966; Hammer et al., 2001). Two main clusters can be distinguished in the dendrogram. The first one includes samples 5 and 6 , i.e. the mollusc assemblage with Lithoglyphus jahni and with the higher energy conditions. The second cluster can be subdivided into two parts. One is slightly diverse and contains samples 2, 3 and 4, which represent the assemblage with Valvata piscinalis and Bithynia tentaculata. Generally it is connected with expansion of aquatic plants and some oscillations of water level. The second represents sample 1 and the assemblage with Valvata piscinalis connected with the phase of a deeper lake (Fig. 4).

\section{BIOMETRY OF PISIDIUM MOITESSIERIANUM}

According to Brodniewicz (1960) two ecological forms of Pisidium moitessierianum can be distinguished, which was observed in two sites of the Eemian Interglacial and six recent. In rivers it reaches the length of $2.1 \mathrm{~mm}$, in lakes only $1.7 \mathrm{~mm}$. Fluvial forms are characterized by similar dimensions of the shell length and height, with the ratio of 1.02 , whereas juvenile specimens are relatively longer $\mathrm{L} / \mathrm{H}=1.17$. In lacustrine forms, in every stage of growth, the length of shell is greater than its height. The length to height ratio $(\mathrm{L} / \mathrm{H})$ differs between young and mature individuals from 1.14 to 1.11 (Brodniewicz, 1960).

A total of 129 shells of $P$. moitessierianum were measured at Roskosz. Because it is absent in the sample 2 and has low numbers in samples 3 and 4 , results from samples 1,5 and 6 are only presented (Table 2). The length of shell varies from 1.1 to $1.8 \mathrm{~mm}$, whereas the shell height ranges from 1.0 to $1.72 \mathrm{~mm}$. In all samples the greatest number of shells appears in the length interval of 1.4-1.6 mm and the height interval of 1.2-1.4 mm (Table 2). Similar data are presented by Brodniewicz (1960) for recent lacustrine form. Distribution of shells with the most abundant L/H classes of $1.05-1.10$ and $1.10-1.15$ also resembles results given for lake 
Malacofauna of the Wilczyn $1 / 12$ profile

\begin{tabular}{|c|c|c|c|c|c|c|c|c|c|}
\hline \multirow{2}{*}{ I } & \multirow{2}{*}{ II } & \multirow{2}{*}{ Taxon } & \multicolumn{7}{|c|}{ Samples } \\
\hline & & & 1 & 2 & 3 & 4 & 5 & 6 & 7 \\
\hline 5 & So & Vallonia pulchella (Müller) & & $1 ?$ & & & & & \\
\hline 9 & WD & Succinea putris (Linnaeus) & & & & 1 & & & \\
\hline 10 & WP & Valvata macrostoma (Müller) & & & & $1 ?$ & & & \\
\hline 11 & We & Viviparus diluvianus (Kunth) & $1+d$ & $4+d$ & $3+d$ & $2+d$ & $3+d$ & $2+d$ & $2+d$ \\
\hline 11 & We & $\begin{array}{l}\text { Bithynia tentaculata (Linnaeus) } \\
\text { (+operculum) }\end{array}$ & $\begin{array}{c}4 \\
43\end{array}$ & 35 & 37 & $\begin{array}{c}5 \\
64\end{array}$ & 54 & $\begin{array}{c}3 \\
85\end{array}$ & $\begin{array}{c}3 \\
36\end{array}$ \\
\hline 11 & We & Lithoglyphus jahni Urbański & 2 & 2 & 4 & 9 & 6 & 7 & $8+k$ \\
\hline 11 & We & Valvata piscinalis Müller & 111 & 104 & 111 & 150 & 106 & 133 & 121 \\
\hline 11 & WL & $\begin{array}{l}\text { Valvata piscinalis f. antiqua } \\
\text { Sowerby }\end{array}$ & 37 & 31 & 15 & 19 & 14 & 10 & 19 \\
\hline 11 & We & Pisidium casertanum (Poli) & 1 & 1 & 1 & 1 & & 1 & 1 \\
\hline 11 & We & $\begin{array}{l}\text { Pisidium casertanum } \mathrm{f} . \\
\text { ponderosa Stelfox }\end{array}$ & & & & & & 1 & \\
\hline 11 & We & Pisidium henslowanum (Sheppard) & & 1 & & & & & \\
\hline 11 & Wp & Pisidium obtusale lapponicum & & & 1 & 1 & & & \\
\hline 11 & WL & Pisidium hibernicum Westerlund & & & 1 & & & & \\
\hline 11 & We & Pisidium moitessierianum Paladilhe & & 1 & & 1 & 1 & 1 & \\
\hline 11 & We & Pisidium crassum Stelfox & & & & 1 & & & \\
\hline 12 & Wc & Pisidium amnicum (Müller) & $1+d$ & $\mathrm{k}$ & $\mathrm{k}$ & $1+k$ & & $1+k$ & $\mathrm{k}$ \\
\hline 12 & We & Pisidium nitidum Jenyns & & 1 & 2 & 1 & & 2 & 1 \\
\hline 12 & We & Pisidium subtruncatum Malm & & & & 2 & & 1 & 1 \\
\hline & & Sphaerium sp. & & 1 & $\mathrm{k}$ & $1+k$ & $1+k$ & $\mathrm{k}$ & $\mathrm{k}$ \\
\hline & & Pisidium sp. & $1+k$ & $1+k$ & $1+k$ & $1+k$ & $1+k$ & 2 & $3+k$ \\
\hline
\end{tabular}

5 - open country snails, So - species of open environs of diverse humidity, $k$ - few fragments of shells, ? - identification uncertain, $d$ - shell detritus; for other explanations see Table 1

habitats. The average length/height ratios, which attain 1.09 , 1.11 and 1.10 in samples 6,5 and 1 respectively, are typical of mature lake individuals (cf. Brodniewicz, 1960). Thus the biometry of $P$. moitessierianum seems to confirm the lacustrine origin of sediments.

\section{WILCZYN 1/12 SITE}

\section{MOLLUSC COMPOSITION}

A total of 20 taxa were identified in the Wilczyn 1/12 profile. The mollusc community comprises 8 species of snails and 12 taxa of bivalves with a total amount of 1500 specimens. The number of species and specimens per sample changes from 8 to 15 , and from 185 to 269 respectively. The most numerous population was noted in sample 4 (the depth of 1.4-1.5 m), whereas the poorest one is represented by sample 5 (the depth of 1.5-1.6 m; Fig. 5). Molluscs from Wilczyn 1/12 were classified in 5 ecological groups and 7 supplementary classes (Table 3).

Open country snails (5). Only one specimen of Vallonia pulchella belongs to this group (sample 2) (Table 3 ). It inhabits open environs, meadows, sometimes wet places (Kerney et al., 1983; Wiktor, 2004). Probably accidentally delivered to the community from an adjacent area.

Species of damp and swampy habitat (9). Similarly to the Roskosz site, single individual of Succinea putris was noted in Wilczyn $1 / 12$ in sample 4. Its appearance is not essential for the interpretation (Table 3).
Species of temporary water bodies (10). One snail species - Valvata macrostoma, represented by only one specimen composes this group (Table 3 ). Its appearance is usually connected with episodic, periodically drying out water bodies, sometimes occurs in the littoral of lakes (Piechocki, 1979; Glöer, 2002). It is not significant for the interpretation at Wilczyn.

Species of permanent water bodies of stagnant waters (11). The group contains 5 species of snails and 7 of bivalves. Molluscs present both in stagnant and flowing waters prevail. The most frequent are $V$. piscinalis and $B$. tentaculata, presence of $V$. diluvianus and $L$. jahni is also worth noting. $P$. moitessierianum is less numerous than at Roskosz and is represented only by single specimens. $V$. piscinalis f. antiqua and $P$. hibernicum, typical of lacustrine environs, as well as cold-loving $P$. obtusale lapponicum complete the assemblage (Table 3).

Species of flowing waters (12). Three species of bivalves belong to this group: $P$. amnicum, $P$. nitidum and $P$. subtruncatum. They are the accessory component of the fauna (Table 3).

\section{MOLLUSC ASSEMBLAGE AND THE ENVIRONMENT}

The mollusc assemblage from Wilczyn $1 / 12$ is typical of freshwater environments. Land snails Vallonia pulchella and Succinea putris are insignificant components of the fauna. In the community representatives of stagnant waters prevails over the fluviatile molluscs. Despite a single shell of Valvata macrostoma they represent a permanent water body (ecologi- 


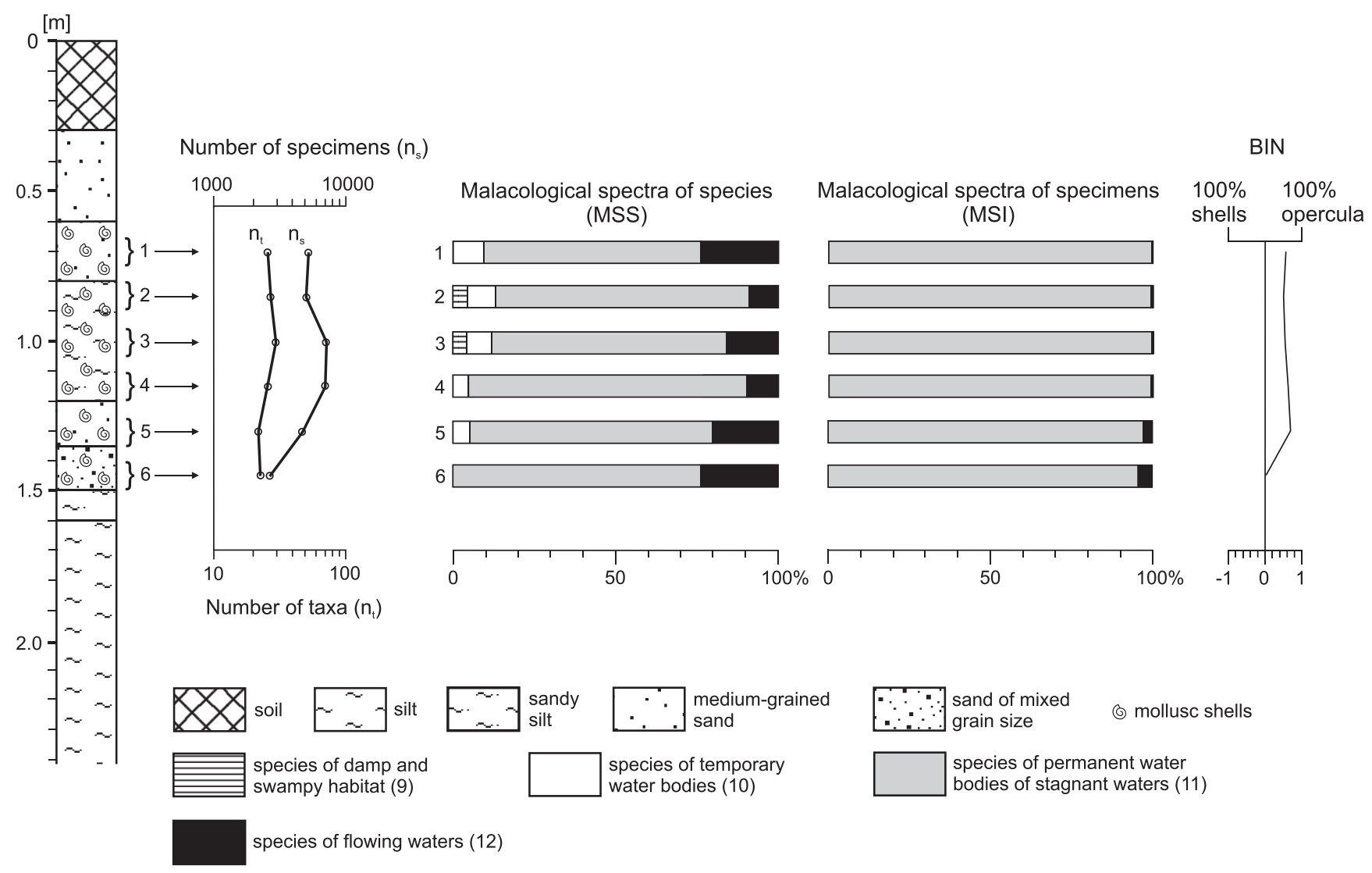

Fig. 2. Malacological spectra and Bithynia-index (BIN) of the Roskosz profile

cal group 11). It was a lake with the abundant form V. piscinalis f. antiqua. Species of flowing waters (group 12) are less common, with the greatest frequency in the lowermost part of the section (samples 7 and 6). They constitute up to $33 \%$ of all taxa, but only a few percent if regarding the total amount of individuals. This tendency occurs in the whole profile (Fig. 5). It may suggest weak wave action, which was totally restricted in sample 5, where rheophile species are absent.

Three snail species dominate in the Wilczyn malacocenoses $-V$. piscinalis, $B$. tentaculata and $V$. piscinalis $f$. antiqua. The first makes up between 52 and $60 \%$ of all species and is the most numerous in samples 7 and 3 . Some fluctuations in its number correspond with the higher abundance of $B$. tentaculata. The latter is most frequent in samples 6,5 and 4 (between 34 and $25 \%$ of the assemblage) and drops gradually to ca. $18 \%$ in sample 2 (Fig. 6). These changes may be related to slight oscillations of water level, but it is not certain. In sediments mainly opercula of $B$. tentaculata are present, which documents the reed zone of the lake (BIN between 0.83 and 1). Thus rather a shallow littoral environment is inferred. However, a lack of pulmonate snails indicates accumulation below the depth of $2-3 \mathrm{~m}$ (Alexandrowicz, 1987). V. piscinalis f. antiqua is also common. It participates in 4-9\% in the community from the lower part of the profile and attains $16-18 \%$ in samples 2 and 1 (Fig. 6). V. diluvianus and L. jahni are of secondary importance. They constitute no more than $5 \%$ of the fauna and $V$. diluvianus is represented mostly be shell detritus (Table 3 ). Bivalves are rather rare. $P$. obtusale lapponicum noted in samples 3 and 4 may point to somewhat cooler conditions (Piechocki and Dyduch-Falniowska, 1993; Skompski, 1996). Deterioration of the climate may be also suggested by a significant drop in the number of taxa in the uppermost part of the section (Fig. 5).

\section{CLUSTER ANALYSIS}

Clustering at Wilczyn provided a dendrogram with two distinct groups of samples (Fig. 7). Firstly samples from the uppermost part of the section (1 and 2; depth of 1.1-1.3 m) were joined together. They are characterized by the community with abundant $V$. piscinalis, $V$. piscinalis $f$. antiqua and $B$. tentaculata. The second cluster is composed of two units. The first one with samples 4, 5 and 6 (depth of 1.4-1.7 $\mathrm{m}$ ) is connected with the higher proportion of $B$. tentaculata and a zone of reeds. The second covers samples 3 and 7 (1.3-1.4 $\mathrm{m}$ and $1.6-1.7 \mathrm{~m}$ ) and corresponds to the highest numbers of $V$. piscinalis in the assemblage and probably deeper habitats (Fig. 7).

\section{POLLEN ANALYSIS}

The pollen spectra of lacustrine sediments from Wilczyn $1 / 12$ are rather poor. In the uppermost part of the succession, at the depth of 1.1-1.2 $\mathrm{m}$ no pollen grains were found. The material was probably strongly processed in a dry, continental climate. In most samples (the depth of 1.2-1.3 m and 1.4-1.9 m) the pollen is abundant but preserved in bad condition. Sporomorphs of various ages with both Paleogene and Neogene elements and dinocysts are present. The stratigraphical range of the samples is hard to estimate (K. Bińka, pers. comm., 2013). 


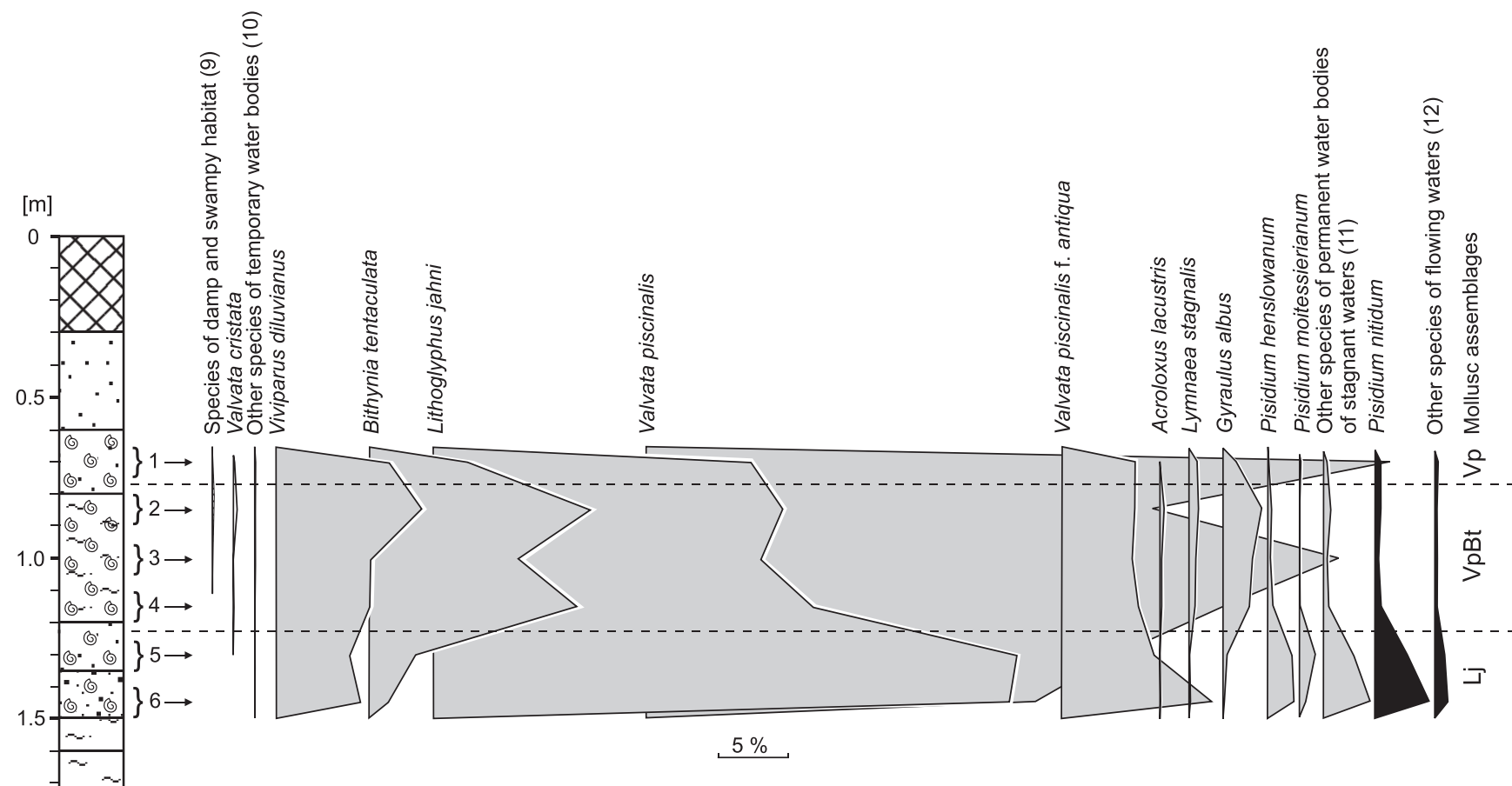

Fig. 3. Malacological diagram and mollusc assemblages of the Roskosz profile

$\mathrm{Lj}$ - assemblage with Lithoglyphus jahni; VpBt - assemblage with Valvata piscinalis and Bithynia tentaculata; $\mathrm{V} p$ - assemblage with Valvata piscinalis; for other explanations see Figure 2

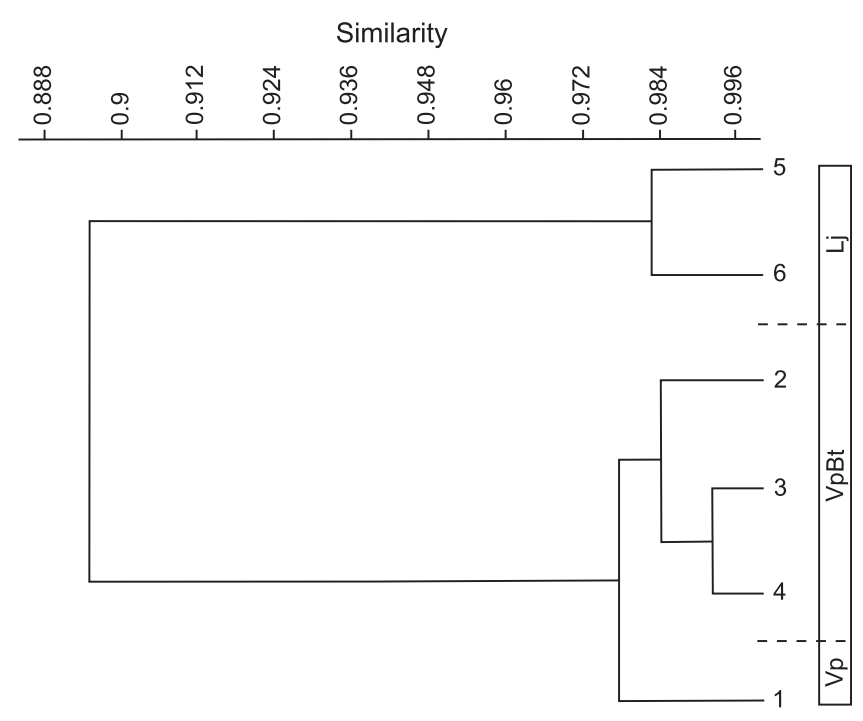

Fig. 4. Cluster analysis of molluscs from Roskosz

For explanations see Figure 3

Only the pollen spectrum from the depth of 1.3-1.4 $\mathrm{m}$ (sample 3) can be interpreted (Table 4). Dinocysts as well as Paleogene and Neogene pollen are less numerous. The pollen of Pinus and Betula prevails in the sediment with some admixture of other trees and bushes, e.g. Carpinus. Herbaceous plants are quite abundant with a high frequency of Poaceae and Artemisia. Also noteworthy is the occurrence of Salvinia, but only single spores are present (Table 4). It is typical of quiet, shallow and overgrown water bodies and reaches high frequencies in the optimal and post-optimal part of the Holsteinian Interglacial. However, the pollen spectrum indicates rather cooler conditions and is reminiscent of the final stage of the interglacial with sparse pine-birch forests, noted in the nearby Wilczyn (WL-1) and Kaliłów profiles (Bińka and Nitychoruk, 1996; Bińka et al., 1997). It seems that the presence of some warm-demanding pollen may be connected with its redeposition. The accumulation in the first interstadial period of the Saalian Glaciation or transition interglacial/glacial cannot be excluded (K. Bińka, pers. comm., 2013).

\section{DISCUSSION}

Mollusc assemblages from Roskosz and Wilczyn 1/12 were taken from different parts of the same palaeolake of the Holsteinian age. As evidenced by the pollen spectra of sediments, they are not synchronous. Samples from Roskosz are older and probably represent some part of the interglacial optimum, whereas molluscs from Wilczyn $1 / 12$ should be rather connected with the final part of the Holsteinian (Mazovian) Interglacial (Fig. 8). The latter is supported by a higher abundance of pine, birch and some herbaceous plants. Unfortunately, the exact position of other samples is hard to define due to very poor pollen spectra.

Mollusc assemblages under investigation share some similarities but they differ in many aspects. Both are typical of lacustrine environments. Fluvial specimens occur in rather inconsiderable amounts; however, currents are more evident at Roskosz, in the lowermost part of the profile. This is recorded by greater numbers of Pisidium nitidum and $P$. henslowanum, 


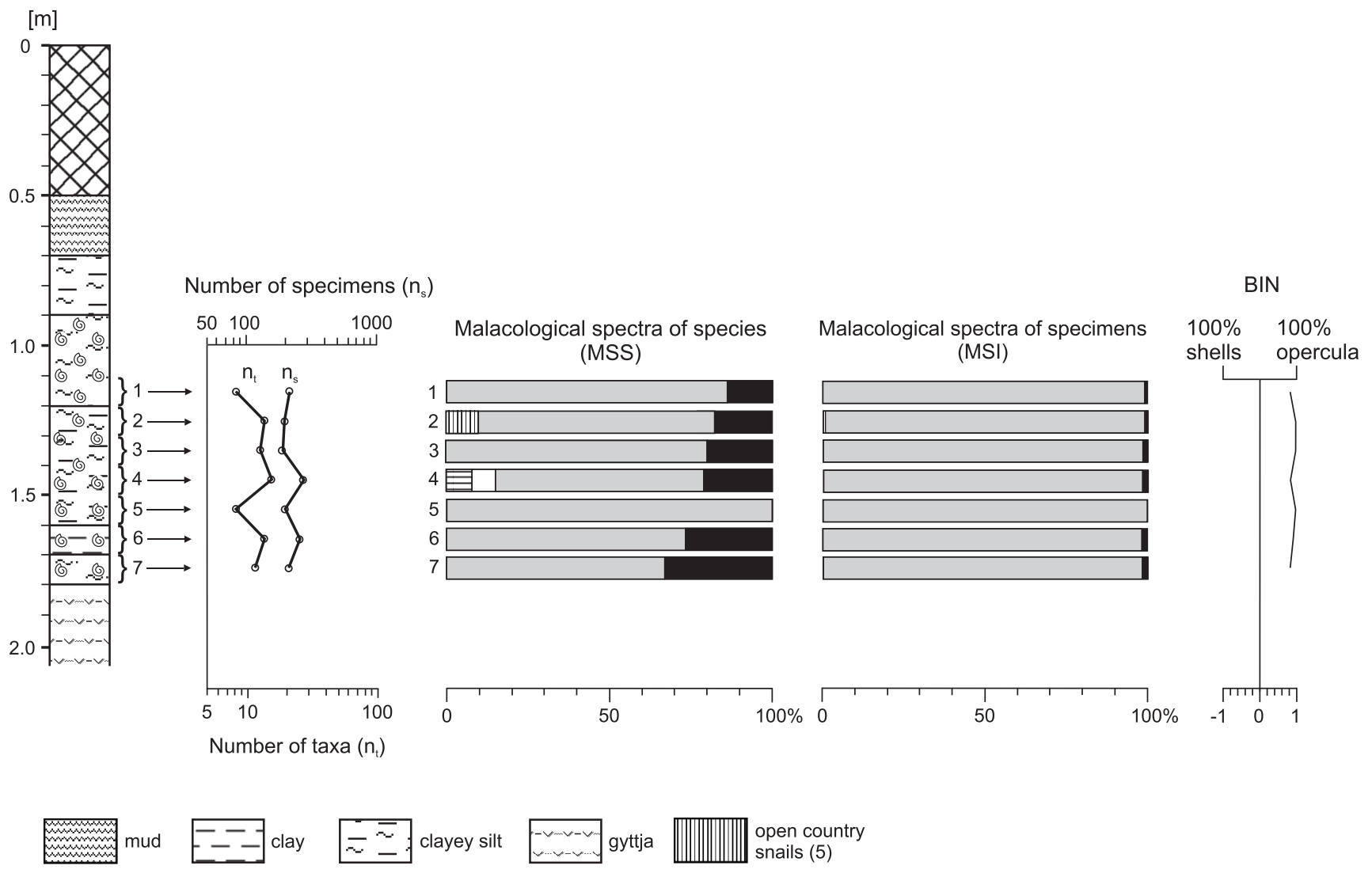

Fig. 5. Malacological spectra and Bithynia-index (BIN) of the Wilczyn 1/12 profile

For other explanations see Figure 2
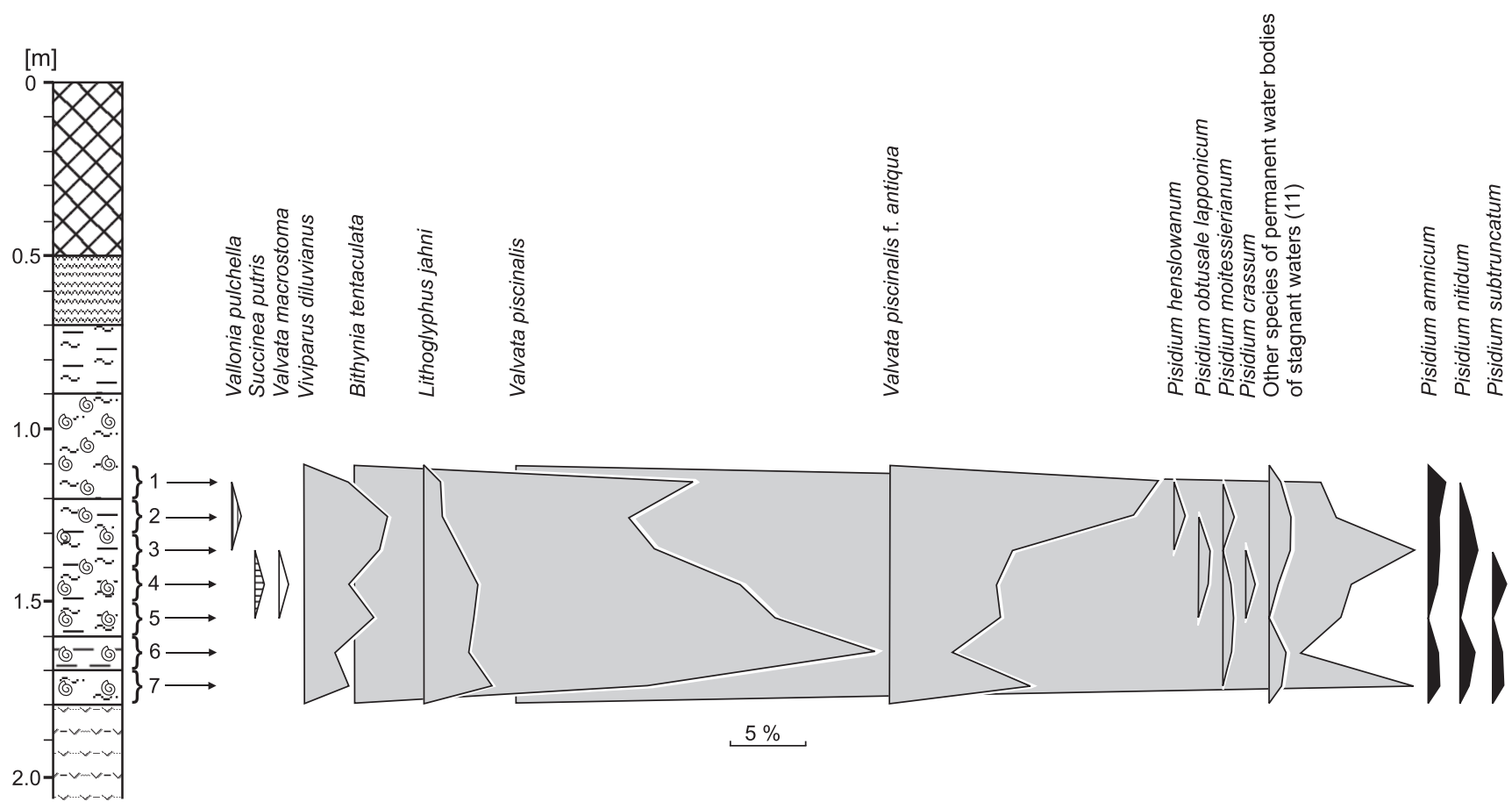

Fig. 6. Malacological diagram of the Wilczyn $1 / 12$ profile

For explanations see Figures 2 and 5 


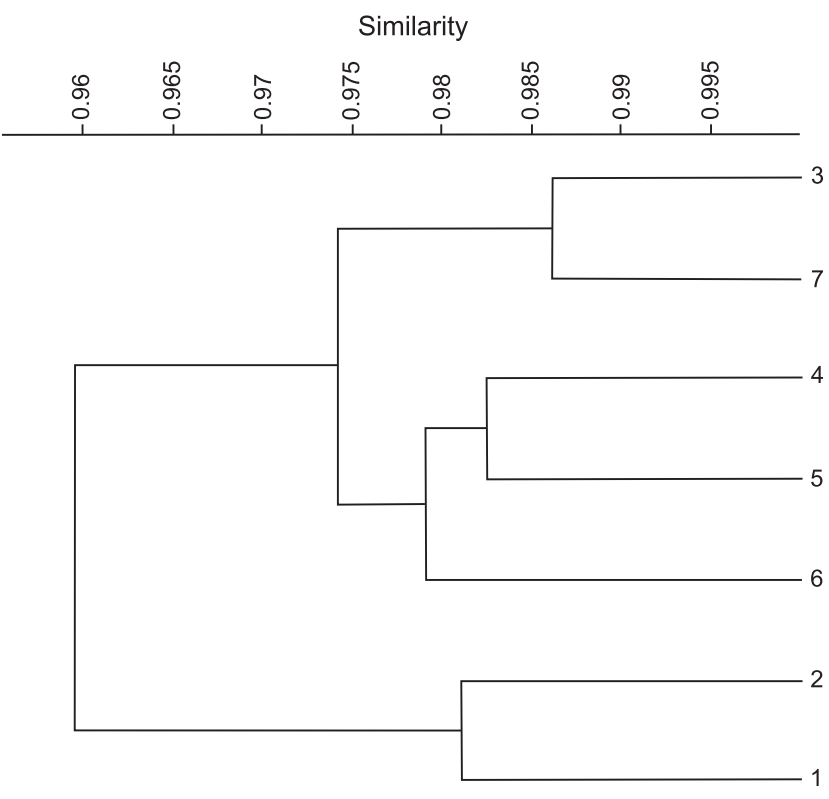

Fig. 7. Cluster analysis of molluscs at Wilczyn 1/12

Table 4

Pollen spectrum of lake deposits of Wilczyn 1/12 profile

\begin{tabular}{|l|}
\hline \multicolumn{1}{|c|}{ Sample 3 (1.3-1.4 m) } \\
\hline Pinus -115 \\
Betula -59 \\
Larix -1 \\
Quercus -2 \\
Carpinus -3 \\
Corylus - 2 \\
Alnus -7 \\
Picea -2 \\
Abies -1 \\
Juniperus -1 \\
Ericaceae -1 \\
Artemisia -6 \\
Poaceae -21 \\
Polypodiaceae -9 \\
Pediastrum -9 \\
Nymphaea - 1 \\
Typha latifolia - 1 \\
Salvinia - 1 \\
Pteridium aqulinum - 2 \\
\hline
\end{tabular}

115 - number of pollen grains

which suggest some overflow through the lake. Signs of the higher energy conditions disappear in the upper part of the section and in the Wilczyn 1/12 profile (Fig. 8).

The main differences are visible in the composition of molluscs. Malacocenoses from Roskosz is more diverse and comprises more taxa. The latter may suggest better conditions for faunal development than in the Wilczyn $1 / 12$ profile. However, they were not stable. Three distinct assemblages, connected with following phases of lake evolution, can be distinguished. The assemblage with Lithoglyphus jahni covers the lowest samples with documented overflow. Habitats of this species are still uncertain, however, it is possible that its occurrence is connected with currents (cf. Gittenberger et al., 2004; Kondrashov, 2007), depth conditions (cf. Lindner et al., 1991; Szymanek, 2012) or changes in the aquatic vegetation. A similar sequence was noted in the nearby Hrud profiles (Lindner et al., 1991; Szymanek, 2012). However, the maximum of L. jahni

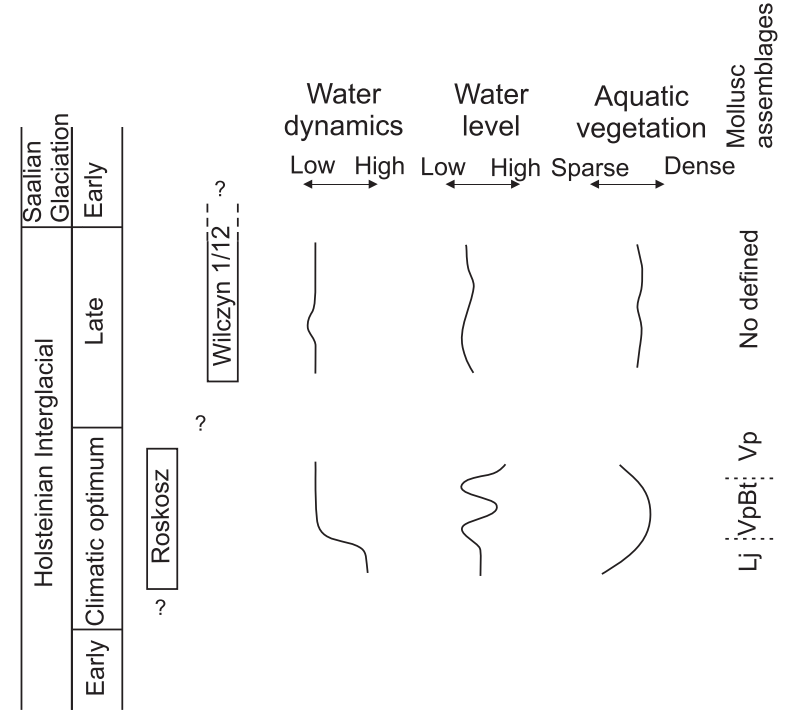

Fig. 8. Scheme of ecological changes in the Wilczyn lake based on malacological studies

For explanations see Figure 3

coincides there with the pre-optimal and optimal periods. Deposits enriched in $L$. jahni shells were also described in other Holsteinian sites e.g., Opole (Skompski, 1989) as well as in the Augustovian Interglacial in Sucha Wieś and Czarnucha (Skompski, 2009). No detailed comments on the ecology of this species were made but it was related to favourable thermal conditions (Skompski, 1989). The latter occurs at Roskosz. The second mollusc assemblage with Valvata piscinalis and Bithynia tentaculata records a drop of the water level and overgrowing of the lake. Abundant Bithynia opercula were accumulated in the zone of reeds and bullrushes. Well-vegetated habitats are suggested by some pulmonates (e.g., Lymnaea stagnalis, Gyraulus albus, Acroloxus lacustris). Some oscillations of the water level cannot be excluded at this period. The uppermost assemblage with $V$. piscinalis is joined with deepening of the lake and limited vegetation (Fig. 8). In all assemblages Viviparus diluvianus appears in considerable amounts.

Environmental changes in the late Holsteinian Interglacial are less distinct (Fig. 8). The lake was inhabited mostly by $V$. piscinalis, B. tentaculata and $V$. piscinalis $\mathrm{f}$. antiqua. The number of $L$. jahni and $V$. diluvianus is significantly limited. They are usually related to warm periods, thus some deterioration of the thermal conditions may be inferred at Wilczyn 1/12. Warm-demanding $P$. moitessierianum is also scarce and Gyraulus albus completely disappears. In addition arctic and sub-arctic $P$. obtusale lapponicum appears in the lake. However, $B$. tentaculata, also regarded as a species with higher climatic demands, is quite abundant. Its number fluctuates, which coincides with greater numbers of dominating in the section Valvata piscinalis. Some water level changes occurred at that time (Fig. 8), which is also evidenced in pollen spectra of nearby Kaliłów and Wilczyn profiles (Bińka and Nitychoruk, 1996; Bińka et al., 1997). In the shore zone, the reed beds were still present, but no plant-associated pulmonate snails occur. The lake still existed in the final part of the interglacial; however, the mollusc assemblage was sparser than in its optimal part. For sure it survived until beginning of the Saalian Glaciation, which is documented in the pollen spectra from Kaliłów and Wilczyn (WL-1), 
however, no molluscs were found in the sediments of that age (Bińka and Nitychoruk, 1996; Bińka et al., 1997).

Mollusc communities dominated by $V$. piscinalis and/or $B$. tentaculata are common in lake deposits of different age. They appear in the Bavelian (Augustovian) Interglacial (Skompski, 2009), in other sites of the Holsteinian Interglacial (Skompski, 1989, 1996; Albrycht et al., 1995; Szymanek et al., 2005; Szymanek, 2011, 2012), in the Eemian Interglacial (Skompski, 1983; Alexandrowicz, 2008; Alexandrowicz and Alexandrowicz, 2010) as well as in the Late Glacial and Holocene (Alexandrowicz W.P., 1999, 2002, 2007, 2009; Wojciechowski, 2000; Apolinarska and Ciszewska, 2006; Alexandrowicz and Żurek, 2010; Sanko et al., 2010). Because some sequences of older interglacials are not complete, it is hard to conclude precisely on the ecology of the aforementioned species. In sections which cover the entire succession, relations between $V$. piscinalis and $B$. tentaculata can be observed in detail. $V$. piscinalis usually appears earlier in geological profiles. It is abundant in pre-optimal parts of the Eemian Interglacial as well as in the Late Glacial sediments. The expansion of $B$. tentaculata begins in higher parts of the Eemian successions and during the Holocene (Alexandrowicz W.P., 1999, 2002, 2007, 2008; Alexandrowicz and Alexandrowicz, 2010; Sanko et al., 2010). Then they occur together in the water bodies but some fluctuations in their abundance are noted. Both species are also numerous in post-opti- mal period of the Eemian, for example at Żmigród (Skompski, 1983; Alexandrowicz and Alexandrowicz, 2010) and Świątniki (Alexandrowicz, 1988; Alexandrowicz and Alexandrowicz, 2010).

\section{CONCLUSIONS}

Mollusc assemblages from Roskosz and Wilczyn 1/12 document the evolution of the Holsteinian palaeolake. They record environmental conditions in the main phase of the lake's existence in the climatic optimum as well as in the final stage of the interglacial. Diversity of mollusc communities enables to distinguish the phase of a lake with overflow, periods of a fall in the water level and the expansion of aquatic plants with reed zones near the shore, as well as a rise in the water level in the climatic optimum. The deterioration of the climate is documented at the end of interglacial but molluscs still existed in quite considerable amounts. No evidence for post-interglacial fauna was found.

Acknowledgements. The present study was financially supported by scientific projects DSM-100600/4 and DSM-102915, sponsored by Faculty of Geology, University of Warsaw. I am extremely grateful to K. Bińka for palynological expertise. The valuable comments of three anonymous reviewers on the manuscript are highly appreciated.

\section{REFERENCES}

Albrycht A., Skompski S., Pidek I.A. (1995) Significance of mollusk fauna from Ortel Królewski and Rossosz sites for the Quaternary stratigraphy of Podlasie (East Poland) (in Polish with English summary). Przegląd Geologiczny, 43: 321-330.

Albrycht A., Bińka K., Brzezina R., Dyjor K., Nitychoruk J., Pawłowskaja I. (1997) New sites of interglacial deposits against a background of stratigraphy of younger Quaternary of southern Podlasie, eastern Poland (in Polish with English summary). Przegląd Geologiczny, 45: 629-634.

Alexandrowicz S.W. (1987) Malacological analysis in Quaternary research (in Polish with English summary). Geologia, 12.

Alexandrowicz S.W. (1988) Zespoły mięczaków z osadów eemskich w Świątnikach na Wyżynie Łódzkiej. Sprawozdania z Posiedzeń Komisji Naukowych PAN, Oddział w Krakowie, 29: 355-357.

Alexandrowicz S.W. (1999) Bithynia tentaculata (Linnaeus, 1758) as an indicator of age and deposition environment of Quaternary sediments. Folia Malacologica, 7: 79-88.

Alexandrowicz S.W., Alexandrowicz W.P. (2010) Molluscs of the Eemian Interglacial in Poland. Annales Societatis Geologorum Poloniae, 80: 69-87.

Alexandrowicz S.W., Alexandrowicz W.P. (2011) Analiza malakologiczna. Metody badań i interpretacji. Rozprawy Wydziału IV Przyrodniczego PAU, T. 3. Wydawnictwa PAU. Kraków.

Alexandrowicz W.P. (1999) Evolution of the malacological assemblages in North Poland during the Late Glacial and Early Holocene. Folia Quaternaria, 70: 39-69.

Alexandrowicz W.P. (2002) Mollusc assemblages of an ancient lake in Różyny near Skowarcz (Żuławy Wiślane, North Poland). Folia Malacologica, 10: 215-224.

Alexandrowicz W.P. (2004) Molluscan assemblages of Late Glacial and Holocene calcareous tufas in southern Poland. Folia Quaternaria, 75: 3-309.
Alexandrowicz W.P. (2007) Malacofauna of Late Glacial and Holocene calcareous lake deposits in North Poland (in Polish with English abstract). Geologia, 33: 395-420.

Alexandrowicz W.P. (2008) Mollusc fauna from deposits of the Eemian interglacial in Piła (in Polish with English summary). Prace Komisji Paleogeografii Czwartorzędu PAU, 6: 49-57.

Alexandrowicz W.P. (2009) Changes of environment of Lake Wigry during Late Glacial and Holocene in the light of molluscan analyses. In: Wigry Lake. History of the Lake in the Light of Geological and Paleoecological Studies (eds. J. Rutkowski and L. Krzysztofiak): 227-240. Man and Nature Association. Suwałki.

Alexandrowicz W.P., Sanko A.F. (1997) Malacofauna and calcareous deposits in the Ptich Valley (Minsk Upland, Belarus). Folia Quaternaria, 68: 203-211.

Alexandrowicz W.P., Żurek S. (2010) Malacofauna of Gajlik mire's lake deposits in the Sejny Lake District (North-Eastern Poland) (in Polish with English summary). Geologia, 36: 491-504.

Apolinarska K., Ciszewska M. (2006) Late Glacial and Holocene lacustrine molluscs from Wilekopolska (central Poland) and their environmental significance. Acta Geologica Polonica, 56: $51-66$.

Bińka K. (1994) Ewolucja interglacjalnych zbiorników w Wilczynie i Woskrzenicach na Podlasiu w świetle analizy paleobotanicznej. PhD Thesis. Faculty of Geology, University of Warsaw. Warsaw, Poland.

Bińka K., Nitychoruk J. (1995) Mazovian (Holsteinian) lake sediments at Woskrzenice near Biała Podlaska. Geological Quarterly, 39 (1): 109-120.

Bińka K., Nitychoruk J. (1996) Geological and palaeobotanical setting of interglacial sediments at the Kalitów site in southern Podlasie. Geological Quarterly, 40 (2): 269-282.

Bińka K., Lindner L., Nitychoruk J. (1997) Geologic-floristic setting of the Mazovian Interglacial sites in Wilczyn and Lipnica in southern Podlasie (eastern Poland) and their palaeogeographic connections. Geological Quarterly, 41 (3): 381-394. 
Brodniewicz I. (1960) A comparison of the recent and Pleistocene populations of Pisidium moitessierianum Paladilhe (Lamellibranchiata) (in Polish with English summary). Acta Palaeontologica Polonica, 5: 349-365.

Glöer P. (2002) Die Süßwassergastropoden Nord- und Mitteleuropas. Bestimmungsschlüssel, Lebensweise, Verbreitung. Die Tierwelt Deutschlands, 73. ConchBooks. Hackenheim.

Gittenberger E., Janssen A.W., Kuijper W.J., Kuiper J.G.J., Meijer T., van der Velde G., Vries J.N. de (2004) De Nederlandse Zoetwatermollusken: Recente en fossiele weekdieren uit zoet en brak water. Nederlandse Fauna 2. Nationaal Natuurhistorisch Museum Naturalis. KNNV Uitgeverij and EISNederland. Leiden.

Hammer Ř., Harper D.A.T., Ryan P.D. (2001) PAST: paleontological statistics software package for education and data analysis. Palaeontologia Electronica, 4: 1-9.

Horn H.S. (1966) Measurement of overlap in comparative ecological studies. American Naturalist, 100: 419-424.

Kerney M.P., Cameron R.A.D., Jungbluth J.H. (1983) Die Landschnecken Nord- und Mitteleuropas. Verlag Paul Parey. Hamburg und Berlin.

Kondrashov P.E. (2007) New gastropod species from the Pleistocene of the upper Don basin. Paleontological Journal, 41: 513-519.

Körnig G. (1966) Die Molluskengessellschaften des mitteldeutschen Hügellandes. Malakologische Abhandlungen. 11: 57-85.

Krupiński K.M. (1995) Pollen stratigraphy and successions of vegetation during the Mazovian Interglacial. Acta Geographica Lodziensia, 70: 1-200.

Krupiński K.M. (2000) Palynostratigraphic correlation of deposits of the Mazovian Interglacial of Poland (in Polish with English summary). Prace Państwowego Instytutu Geologicznego, 169: $1-61$.

Krupiński K.M., Skompski S. (1995) Viviparus diluvianus (Kunth) in the sediments of Mazovian Interglacial from Grabanów in Podlasie (E Poland) (in Polish with English summary). Przegląd Geologiczny, 43: 1045-1048.

Lindner L., Marciniak B. (1997) Middle Pleistocene fossil lakes against a background of the Quaternary stratigraphy in the Janów Podlaski region (eastern Poland) (in Polish with English summary). Przegląd Geologiczny, 45: 484-488.

Lindner L., Marciniak B. (1998) Middle Pleistocene lake deposits in southern Podlasie (eastern Poland). Studia Geologica Polonica, 113: 65-83.

Lindner L., Wyrwicki R. (1996) Pleistocene lacustrine deposits in Grabanów (Podlasie, eastern Poland) (in Polish with English summary). Przegląd Geologiczny, 44: 1131-1134.

Lindner L., Krupiński K.M., Marciniak B., Nitychoruk J., Skompski S. (1991) Pleistocene lake sediments of the site Hrud I near Biała Podlaska (in Polish with English summary). Geological Quarterly, 35 (3): 337-362.

Ložek V. (1964) Quartärmollusken der Tschechoslowakei. Rozpravy Ústředního Ústavu Geologického, 31: 1-374.

Ložek V. (1976) Klimaabhängige Zyklen der Sedimentation und Bodenbildung während Quartärs im Lichte malakozoologischer Untersuchungen. Rozpravy Československé Akademie Věd, 86: $1-97$.

Ložek V. (1982) Faunengeschichtliche Grundlinien zur spät- und nacheiszeitlichen Entwicklung der Molluskenbestände in Mitteleuropa. Rozpravy Československé Akademie Věd, 92.

Nitychoruk J. (1994) Stratigraphy of the Pleistocene and palaeogeomorphology of Southern Podlasie (in Polish with English summary). Rocznik Międzyrzecki, 26: 23-107.

Nitychoruk J. (2000) Climate reconstruction from stable-isotope composition of the Mazovian Interglacial (Holsteinian) lake sediments in eastern Poland. Acta Geologica Polonica, 50: 247-294.

Nitychoruk J., Gałązka D. (2006) Objaśnienia do Szczegółowej mapy geologicznej Polski 1:50 000, arkusz Biała Podlaska (568). Centralne Archiwum Geologiczne Państwowego Instytutu Geologicznego. Warszawa.
Nitychoruk J., Gałązka D. (2008) Szczegółowa mapa geologiczna Polski 1:50 000, arkusz Biała Podlaska (568). Centralne Archiwum Geologiczne Państwowego Instytutu Geologicznego. Warszawa.

Nitychoruk J., Bińka J., Hoefs J., Ruppert H., Schneider J. (2005) Climate reconstruction for the Holsteinian Interglacial in eastern Poland and its comparison with isotopic data from Marine Isotope Stage 11. Quaternary Science Reviews, 24: 631-644.

Piechocki A. (1979) Mięczaki (Mollusca). Ślimaki (Gastropoda). Fauna słodkowodna Polski, 7: 7-173.

Piechocki A., Dyduch-Falniowska A. (1993) Mięczaki (Mollusca). Małże (Bivalvia). Fauna słodkowodna Polski, 7A: 7-185.

Sanko A.F., Vainorius J., Melešytè Ě. (2010) Malacofauna of Holocene freshwater calcareous deposits of Lithuania. Geologija, 52: 16-24.

Skompski S. (1983) Eemian Interglacial molluscans from Żmigród upon the Barycz River (in Polish with English summary). Geological Quarterly, 27 (1): 151-188.

Skompski S. (1989) Molluscs and ostracod fauna of selected sites of the Mazovian Interglacial in Poland. Geological Quarterly, 33 (3/4): 495-524.

Skompski S. (1996) Standard assemblages of malacofauna in different Quaternary stratigraphic units (in Polish with English summary). Prace Państwowego Instytutu Geologicznego, 151: $1-47$.

Skompski S. (2009) Pleistocene fauna in the Sucha Wieś (Ełk Lakeland) and Czarnucha (Augustów Plain) sections, Northeastern Poland (in Polish with English summary). Biuletyn Państwowego Instytutu Geologicznego, 435: 85-96.

Skompski S., Makowska A. (1989) Mięczaki. In: Atlas skamieniałości przewodnich i charakterystycznych cz. 3b. Kenozoik, Czwartorzęd (eds. W. Rühle and E. Rühle): 40-95. Budowa geologiczna Polski, 3. Wydawnictwa Geologiczne, Warszawa.

Steenberg C.M. (1917) Furesoens molluskenfauna. Köngelige Danske Viden skabernes Selskab Skrifter, 8: 78-200.

Szymanek M. (2007) Rekonstrukcja warunków klimatyczno-środowiskowych $\mathrm{w}$ interglacjale mazowieckim na podstawie zmienności muszli ślimaka Viviparus diluvianus (Kunth) w stanowiskach okolic Białej Podlaskiej. Ph.D. Thesis. Faculty of Geology, University of Warsaw, Warsaw, Poland.

Szymanek M. (2008) Viviparus diluvianus (Kunth) in the vicinity of Biała Podlaska as an indicator of climatic-environmental changes in the Mazovian (Holsteinian) Interglacial (in Polish with English summary). Prace Komisji Paleogeografii Czwartorzedu PAU, 6: 19-27.

Szymanek M. (2011) Climate oscillations of the Holsteinian (Mazovian) Interglacial recorded in shell morphometry of Viviparus diluvianus (Kunth, 1865) from eastern Poland. Quaternary International, 241: 143-159.

Szymanek M. (2012) Malacofauna of the Holsteinian lake deposits at Hrud II (eastern Poland) and its ecological significance. Geological Quarterly, 56 (1): 117-126.

Szymanek M., Nitychoruk J., Trammer J., Bińka K. (2005) Influence of climate on the variability of snails of the genus Viviparus in deposits of the Holsteinian (Mazovian) Interglacial from Ortel Królewski, eastern Poland. Boreas, 34: 335-344.

Urbański J. (1975) Lithoglyphus jahni n. sp. aus den Mitteleuropäischen Ablagerungen des Mindel/Riss Interglazials, nebst Bemerkungen über den nordbalkanischen Lithoglyphus fuscus (C. Pfeiffer, 1828) (= L. pyramidatus Moellendorff, 1873) (Gastropoda, Prosobranchia, Hydrobiidae). Bulletin de la Société des Amis des Sciences et des Lettres de Poznań, 15: 107-111.

Wiktor A. (2004) Ślimaki lądowe Polski. Wydawnictwo Mantis. Olsztyn.

Wojciechowski A. (2000) Zmiany paleohydrologiczne w środkowej Wielkopolsce w ciagu ostatnich 12000 lat w świetle badań osadów jeziornych rynny kórnicko-zaniemyskiej. Wydawnictwo Naukowe Uniwersytetu Adama Mickiewicza. Poznań. 